\title{
Empowerment Pattern for Thalasemi Patients in Dr. Soetomo Hospital Surabaya \\ (Study of the Association of Parents with Thalassemia Indonesia, Surabaya)
}

\author{
Saputra Adiwijaya ${ }^{1,2}$, Dor Valda A Aritonang ${ }^{3}$, Mustain Mashud ${ }^{4}$ \\ ${ }^{I}$ Doctoral Candidates for Human Resource, Sociology Development - Postgraduate Airlangga University - Surabaya \\ ${ }^{2}$ Sociology Departement, Faculty of Social and Political Science, Palangkaraya University \\ ${ }^{3}$ Candidates for Master of Administration and Health Policy - Airlangga University - Surabaya \\ ${ }^{4}$ Professor of the Faculty of Social and Political Sciences, Airlangga University - Surabaya \\ s_adiwijaya@ymail.com
}

\begin{abstract}
Thalassemia is a hereditary disease that until now there is no effective treatment for healing, this disease is not contagious and generally attacks children with a variety of typical symptoms that can be detected since the age of a toddler (under five years). In the city of Surabaya there were 520 sufferers, this number was based on data from the administrators gathered in the organization of the POPTI (Association of Indonesian thalassemia Parents) in the city of Surabaya. There is a pattern of empowerment carried out by the management of POPTI in Surabaya to parents whose children suffer from thalassemia, as well as to adult patients. The thing to do is to conduct routine assistance at Dr. Soetomo Surabaya hospital every Tuesday and Wednesday. The purpose of this study is to describe and analyze the pattern of empowerment carried out by POPTI (Association of Parents with thalassemia Indonesia) in Surabaya in the treatment of thalassemia in Surabaya. This study used a qualitative method with a descriptive approach, with the primary data of the study obtained through in-depth interviews with 9 (nine) parents whose children suffered from thalassemia as key informants, the details of which consisted of 3 (three) POPTI administrators in Surabaya and 6 (six) members POPTI city of Surabaya. Based on the results of the analysis and discussion, the conclusions of the study are: 1) The joining of parents in the POPTI city of Surabaya provides many benefits in the care of their children who suffer from thalassemia in Dr. Soetomo Hospital Surabaya; 2) The form of empowerment patterns carried out by parents of elderly patients who are members of the POPTI container in Surabaya starts with routine mentoring which results in a shared value for parents; 3$)$ There is a tiered learning pattern from patients who are considered senior to teach other patients in terms of understanding and ability to understand the flow of care services to thalassemia patients.
\end{abstract}

Keywords: empowerment of patients; thalassemia; assistance to Patients with thalassemia; POPTI surabaya city, dr. soetomo hospital surabaya

\section{Introduction}

Today's development has included empowerment as one that is prioritized in building a nation. This situation is interpreted as the existence of power or autonomy given by the government to the community in order to be able and independent in determining goodness for themselves, or in other words that there is openness from the government to accommodate various kinds of initiatives from groups that are considered to experience powerlessness or vulnerability .

Then empowerment can also be interpreted as one of the solutions for those who experience powerlessness so that they participate in feeling the results of development that they have not fully felt, this is because development is actually considered as something that weakens the position of vulnerable communities, so Suharto ( 2014) empowerment refers to the ability of people, especially vulnerable and weak groups so that they have strength or 
ability in; (a). Fulfill basic needs so that they have freedom, in the sense that they are not only free to express opinions, but are free from hunger, free from ignorance, free from pain. (b). Reach productive resources that enable them to increase their income and obtain the goods and services they need. (c). Participate in the development process and decisions that affect them.

One who experiences helplessness and vulnerability is thalassemia sufferers, most of whom are children, periods of playing happily, and cheerful will be slowly replaced with blood transfusion activities, taking medication, and various kinds of dietary restrictions throughout his life. This situation is compounded by the growth of the body that is hampered, then the skin is blackened, and if it is too late in handling, it will enlarge the spleen and then experience death.

Indonesia is one of the countries included in the group of countries that are at high risk of thalassemia with the number of thalassemia sufferers who continue to increase. In 1994, the number of people with thalassemia reached 500 people. This figure tripled to 1500 people in 2008, in 2009 it rose to 8.3 percent then in 2014 there were 6,647 people. This is known based on data from the Indonesian Thalassemia Foundation (YTI) - Association of Parents with Thalassemia (POPTI). Then for 2015 the number of sufferers recorded increased along with the increase in the birth rate or in other words according to the rate of population growth in Indonesia which was at 1.49 percent with 38 million births in 2014. Meanwhile for 2016 there were 7,238 sufferers of thalassemia, the number of patients with thalassemia major and will continue to increase from year to year. and predicted by 2020, the number of people with Thalassemia has increased dramatically to 22,500 people (Wahidayat, 2009).

Then also according to data from the 2015 Basic Health Research Ministry of Health (Riskesdas), there were 7,029 cases of Thalassemia in Indonesia. This data increased from 2014 with 6,647 cases. This data is reinforced based on data from the Thalassemia Indonesia Foundation, the number of cases of thalassemia as many as 8,011 in May 2017. The number also increased dramatically when compared to 2011 which only 4,431 cases. (https://jpp.go.id/humaniora/kesehatan/305925-pengidap-thalasemia-di-indonesia-capai-8011-case).

For national policy, thalassemia sufferers have been guaranteed by the government through the Jamkesmas (Community Health Insurance) program from 2008 to the present to change with the name BPJS (Social Security Agency) through JKN (National Health Insurance). Then also for the control program, the government implemented a thalassemia prevention program with the aim of reducing the number of thalassemia major / homozygous patients in Indonesia. Then specifically the Ministry of Health also issued a policy stating that the government guaranteed the cost of treating thalassemia patients, based on the Regulation of the Minister of Health No. 1109 / Menkes / Per / VI / 2011. With this regulation all thalassemia patients in Indonesia are guaranteed the treatment of thalassemia called Jampelthas.

In the city of Surabaya there has been an Association of Parents with Thalassemia Indonesia (POPTI) based on data collected by POPTI administrators the number of patients recorded per July 2017 as many as 520 people, in the organization used as a forum to share experiences and discuss each other in caring for children suffering from thalassemia, then there are also many kinds of activities carried out by this community, and the main thing is to strengthen each other between sufferers to exchange information among parents whose children suffer from thalassemia. 
For the organization of the Association of Parents of Indonesian Thalassemia (POPTI) in Surabaya, the empowerment that is carried out is related to the knowledge of parents in the form that parents understand and know the needs of their children who suffer from thalassemia, for example, when delivering children when blood transfusions are very important. because if it gets negligent it will have a serious effect on the child suffering from thalassemia, then also the schedule for taking medication and giving vitamins. One of the things that has been done by this community is by holding regular meetings twice a week on Tuesday and Wednesday in the inpatient room of the Dr. Children's Hospital Soetomo City of Surabaya and space in the poly paliantif section.

\section{Research Methods}

In the research of empowerment of parents who are members of the organization POPTI (Association of Parents with Thalassemia Indonesia) Surabaya city will try to reveal the uniqueness of individuals or groups, to organizations in their daily lives in a comprehensive and naturally detailed (natural setting). So that a description of speech, writing, or observable behavior from an individual, group, community or organization is reviewed from a complete and comprehensive perspective.

So the type of research used is to use qualitative methods with descriptive approaches. Research can possibly explore and understand the meaning of interacting results with information, find out about the life forms, observe and follow information about life in what form, or in other words this qualitative approach also aims to explore the substance of reality in society to match their understanding with transforming it into research themes. By Strauss \& Corbin (1990) that qualitative research is more feasible in the field of social science and behavior because it is related to interactions and interrelations in human behavior and roles both in organizations, groups, and individuals. Then also by Bogdan \& Biklen (1998) explained that qualitative research typically has actual settings, researchers are key instruments, then data is usually descriptive, emphasizes the process, analysis of data is inductive, and interpretation of meaning and each the event became the main research.

\section{Results and Discussion}

Ideally empowerment can be interpreted as part of human development, including parents of thalassemia patients, and then this situation is described by UNDP (United Nations Development Program) defining human development as an expansion of choice for everyone to live longer, healthier lives and life is more meaningful (UNDP, Human Development Report, 1990). Extending human choice means assuming a decent living condition that allows humans to gain access to knowledge and education and access to the resources needed to live properly (Chakraborty, 2002). Human development can also be interpreted as building a person's ability through improving the level of health, knowledge or education and skills (Suhandojo, 2002).

\section{a. Parent Patient and POPTI}

Being empowered can be seen from the initial state of an individual or group of people who experience helplessness, when then these individuals gather into one group as a force, that empowerment is also formed. This condition of helplessness is experienced by 
parents whose children suffer from thalassemia before the formation of POPTI in Surabaya. This can be seen from their experience when delivering their children when performing routine controls that make the patient's parents feel uncomfortable with the services provided by the hospital. This situation seems to be increasingly not conducive for the care of children suffering from thalassemia because of confusion each month having blood transfusions, queuing for drugs and vitamins, or also when the blood stock runs out, but also added to the feeling of inferiority for parents with thalassemia, or also the child himself who feels inferior in front of his friends, because they are different from normal children in general.

The situation experienced by parents whose children suffer from thalassemia according to Suharto (2014) that they belong to a group of weak and powerless. This helplessness causes them to be weak in a bargaining position in front of other community members and of course with the hospital while undergoing routine maintenance every month. This weak condition can be seen internally that it is based on their own perceptions or externally that they experience oppression by unfair social structures. Furthermore, the division of weak and powerless groups includes:

1. Structurally, both groups are weak in class, gender, and ethnicity.

2. Special weak groups, such as seniors, children and adolescents, people with disabilities, gays and lesbians, isolated communities.

3. Personally weak groups, namely those who experience personal problems and / or family.

These weak people are susceptible to continuous helplessness because they are different from the "generality" of the community, so they are deviant until they are not or underappreciated and even get labeling (stereotypes) ) as a lazy, weak person, caused by himself. However, this might actually be a result of injustice, ignorance, and discrimination in certain aspects of life.

Empowering the parents of patients whose children suffer from thalassemia can be understood as an effort for parents to get care and treatment from the hospital to get better services. This treatment and treatment is of course adapted to the needs of children suffering from thalassemia, such as getting blood from transfusions, getting additional drugs and vitamins, when children are also getting space so that they are not like normal children, such as when they are not tired when doing sports, or also get a dispensation when you have to get routine permits every month for blood transfusions.

The joining of parents of thalassemia patients into the container POPTI (Association of Parents with Thalassemia Indonesia Patients) in Surabaya city as a positive step, because in this organization the ease of carrying out treatment, and consultation with doctors who handle it to be better. Then in another part, in the POPTI container in Surabaya, the management is a parent whose child has thalassemia in this case especially mothers, they help each other - helping in helping this organization especially at the time set for thalassemia patients, in other words they this is what accompanies parents whose children suffer from thalassemia or to adult patients who also suffer from thalassemia.

Alternately, these mothers showed a treatment room, a place for taking prescriptions and medicines, ensuring that the doctors were always at the place on Tuesday and Wednesday which is a routine schedule for people with thalassemia. Since the hospital opened in those days they have been waiting for patients to come to be directed, for Tuesday patients who come are generally children who are delivered by their parents and for Wednesday are generally adult patients. From this situation, it can be understood that with the 
establishment of the POPTI in Surabaya as a place that can truly provide benefits for parents and sufferers, there are many conveniences and other useful things when parents gather in this organization.

\section{b. Creation of a sense of togetherness}

In another part, the establishment of the POPTI institution in the city of Surabaya was also in the background of the sense of belonging as a group of parents whose children suffered from thalassemia, this was what gave birth to the City POPTI of Surabaya. From the beginning, they both took the child to the hospital to carry out blood transfusions, so there was an indirect communication that was intense, knowing each other, telling each other about the problems of children suffering from thalassemia, then having meetings outside of taking care of children or when control also contributes to the closeness between them.

It can be seen later that the existing conditions became different when the POPTI of Surabaya City was formed, because in this institution the parents and children suffering from thalassemia were considered to be siblings (family). There is a feeling of mutual understanding, mutual help when there is a problem, or also there is a feeling of comfort. This situation is not only felt by parents whose children suffer from thalassemia, but also for children with thalassemia, because the hospital is considered as the second home for them to visit every month.

There is a kind of togetherness between parents or families whose children suffer from thalassemia, so that the atmosphere of familiarity grows by itself over time, coupled with a routine schedule every Tuesday and Wednesday to the hospital each week makes the atmosphere of togetherness stronger. Behind routine meetings when conducting routine mentoring on Tuesdays and Wednesdays, the administrators are not not experiencing difficulties, the difficulty experienced is the uncertainty of who the schedule is to control each month is also added usually if there is a shift in the category of patients, from pediatric patients to adult patients are considered difficult.

This bond of sense of togetherness can be said as capital for parents to make it easier to voice what is their focus. Empowerment if linked to the general meaning that there is a concept of power. In this case the existence of social relations between parents who feel helpless when undergoing and caring for children suffering from thalassemia. With this situation the unification of parents whose children suffer from thalassemia in POPTI containers, gives a sense of strength (power) from a sense of togetherness.

This is then according to Ife (2008), empowerment contains two key understandings, namely power and weak groups. Power here is interpreted not only in terms of political power but has a broad meaning which is the control of the community over:

1. Power over choices - personal choices and life opportunities, ability to make decisions about life choices, place to live and work and so on.

2. Power over defining needs, ability to determine needs in harmony with aspirations and desires.

3. Power over ideas or ideas, the ability to express and contribute ideas in interactions, forums and discussions freely and without pressure.

4. Power over institutions, ability to reach, use and influence community institutions such as; educational, health, financial and other life-fulfillment institutions.

5. Power over resources, ability to mobilize formal and informal resources as well as 
community in fulfilling life needs.

6. Power over economic activities the ability to utilize and manage the mechanisms of production, distribution and exchange of goods and services.

7. Power over reproduction, ability in relation to the process of reproduction in a broad sense

such as education, socialization, values and behavior even birth and child care.

The situation of those who experience this discomfort gives birth to a sense of togetherness that strengthens them to have the power (power) that allows parents to have demands to get good service in the hospital when delivering their children who suffer from thalassemia. Then when viewed from the other side that the existing empowerment is a step of participation from parents to be more aware in caring for their children suffering from thalassemia. This participation illustrates that the interactions they have had so far when together bringing their children suffering from thalassemia in the hospital Dr. Soetomo provided a form of mutual awareness that the right to special care and service is something that cannot be ruled out especially by the hospital.

The formation of POPTI later became a further illustration that the helplessness experienced by parents whose children suffer from thalassemia gave birth to a sense of togetherness that made them become empowered, from here it then fostered an awareness of their participation in terms of getting care and care for their children at Dr. Soetomo Surabaya, this situation by Verhangen (1979) in Mardikanto (2010) stated that, participation is a special form of interaction and communication relating to the distribution of authority, responsibility, and benefits. The growth of interaction and communication is based on the awareness of the person concerned about:

a. Conditions that are not satisfactory, and must be corrected

b. This condition can be improved through human activities or the community own

c. His ability to participate in activities that can be done

$\mathrm{d}$. There is confidence, that he can make a useful contribution to the activities concerned

If the parts above are described one by one, the conditions experienced by parents whose children suffer from thalassemia when POPTI has not yet been formed, when they are in the hospital, feel unsatisfactory conditions related to the services provided. With their intense communication, there is an awareness that the conditions that must be improved so far, especially those managed by these parents are the health interests of their children suffering from thalassemia. One voice in stating the importance of making parents whose children suffer from thalassemia have a common goal, that the services provided by hospitals must be satisfying in serving their children.

Then also, the formation of POPTI is also related to that arousing awareness to get maximum service and care is the right of patients, this situation is considered a space for parents to maximize their role. In addition, their understanding of the rules that apply to thalassemia patients is also supported. So then their activities gathered and established intense communication resulted in a forum called POPTI Kota Surabaya. Then this POPTI also has better access to the hospital, plus that the awareness created among these parents makes them able to provide improvements, so far what has been done by POPTI Surabaya is to have a routine schedule every Tuesday and Wednesday in the hospital Dr. Soetomo.

The enthusiasm of other parents whose children suffer from thalassemia also gave encouragement to the administrators of POPTI in Surabaya that the routine schedule conducted every Tuesday and Wednesday was apparently able to arouse the awareness of 
parents to routinely check their children to Dr. Soetomo hospital. The participation of other parents in addition to the POPTI administrators illustrates that this formed container makes it easy for parents to care for and care for children who suffer from thalassemia, it is also added that outside activities they can participate for example socialization on prevention of thalassemia on campus -campus, kelurahan, or other places.

Activities that are meaningful with the aim of facilitating the other members at the POPTI institution in Surabaya provide confidence that what is done provides benefits. The socialization activities that they do with the theme of prevention of thalassemia or also recommendations for screening are some parts of the activities that they often do. This is also supported by doctors, or also usually carried out together with blood donor activities in collaboration with the Indonesian Red Cross (PMI) in Surabaya. This also gives a positive value for the continuity of the Surabaya POPTI institution, and of course the purpose of this institution is to break the chain of thalassemia in Indonesia.

\section{c. Condition of Thalassemia Patients in the Hospital}

The atmosphere of togetherness that exists between parents who have a routine schedule every Tuesday and Wednesday turns out to have an impact on the hospital, there is a kind of acceptance from doctors and nurses for patients with thalassemia. For the weekly schedule, Tuesday is reserved for pediatric patients, and for Wednesday for adult patients, it does not mean that on other days it cannot be done if the emergency conditions of the Surabaya POPTI are ready to assist. This emergency condition, for example when looking for blood for transfusion if the stock in PMI and the hospital is empty, usually the hospital will contact the management, or also when there are patients from outside Surabaya who need to be accompanied, the hospital will usually contact by telephone. Then in the other part the management becomes the liaison between the patient and the doctor or nurse if there is a thalassemia patient who will be given follow-up treatment, this is where the role of the administrator becomes vital.

Likewise when there are patients with thalassemia who have not joined while in the hospital Dr. Soetomo Surabaya when undergoing an examination or treatment, the hospital will contact the POPTI management in Surabaya. This situation generally afflicts referral patients from outside the city of Surabaya, except for the city of Surabaya or the city of Malang, because in the presence of complete equipment for thalassemia patients in East Java Province there are only two hospitals that have blood filter devices namely Dr. Soetomo Surabaya and Dr. Saiful Anwar, Malang city.

To other parties such as drug dealers to doctors or drug marketing (detailers) with administrators can contact each other, for example drugs or vitamins that are usually prescribed to patients out of stock, the administrators can contact to notify if the stock of drugs or vitamins is exhausted. This situation illustrates the existence of good communication between the POPTI management of the city of Surabaya and the hospital, and the drug provider, this situation is certainly built on the basis of the familiarity that has been established, and the feeling of mutual understanding to help each other.

In other parts since the integration of thalassemia patients with Palliative Poly made the condition of patients undergoing examination or treatment at the hospital Dr. Surabaya Soetomo often gets confused. So many other disease patients in Palliative Poly mixed with thalassemia patients make this atmosphere in Palliative Poly like tightness in the halls. As is known, palliative care is a service to patients whose diseases have not reacted to curative 
treatment, or cannot be cured medically (end-stage). The ideal goal of palliative care is to improve the quality of life of patients in dealing with each illness and prepare themselves to face death calmly and comfortably without feeling depressed over the illness, both physically (pain, nausea, vomiting) and psychologically based spiritual.

In Indonesia itself there is actually a provision from the Ministry of Health which states that there must be the application of palliative care for several types of serious diseases. But until now the implementation is still hampered by various things so that there is no maximum palliative care that can be received by patients in the hospital. Even though until now palliative care is often done in cancer patients, but actually there are some diseases that also require this treatment, such as :

- Diseases suffered by adults, are Alzheimer's, dementia, cancer, disease cardiovascular (including with heart attacks), cirrhosis, chronic obstructive pulmonary disease, diabetes, HIV / AIDS, kidney failure, Multiple Sclerosis, Parkinson's, and TB.

- Diseases experienced by children, namely cancer, heart disease and blood vessels, cirrhosis, disorders of the immune system, HIV / AIDS, meningitis, kidney disease, and nervous system problems.

For thalassemia patients in Dr. hospital Soetomo Surabaya already has its own post so that the accompanying management becomes easy to supervise. Since 2000 the hospital has actually provided a special place for thalassemia patients, but it was later excluded because the space used by thalassemia patients has been used by some doctors for rooms and libraries, and until now there has been no specific substitute for thalassemia patients. This situation seems to make thalassemia patients spread mainly on Tuesdays and Wednesdays, when there are many thalassemia patients in those days, then the administrators are made busy. The general thing that is done in assisting patients is to teach adult patients who have just moved from the category of child patients, for example, pointing to the location for taking vitamin drugs, pointing to where the doctor is in charge of them, introducing patients to the doctor. When these patients have been deemed capable, they are the ones who teach new patients, whether they are indeed from the city of Surabaya itself or from other cities that are members of POPTI as well. The pattern of mutual support in this form turned out to be a system that was carried out by the POPTI management of Surabaya city to patients. Administrators who initially provide assistance indirectly introduce patterns of continuous assistance to adult patients, and then patients today provide system lessons like this to other patients, this is then the form of empowerment that exists. But not all patients can easily undergo this because sometimes there are still feelings of inferiority especially patients who come from outside the city of Surabaya, so inevitably the board of three people is always present at the time of control every Tuesday and Wednesday.

Effective and continuous assistance from the POPTI management of Surabaya City to its members indirectly creates commitment and togetherness as a fellow family member suffering from thalassemia. This then becomes a fundamental value for an organization, in setting organizational values is not easy, but the togetherness factor makes fellow thalassemia sufferers unite and have a shared vision which then becomes an organizational culture towards POPTI in Surabaya. This situation is by Robbins (2001) that organizational culture refers to a system of shared meaning by members of the organization towards forms of values, norms, beliefs, traditions and unique ways of thinking adopted, thus distinguishing the organization from other organizations. Then if further illustrated in the context of the city POPTI conditions, according to Bondy and Premeaux (1995) in Roemintoyo (2013) that the 
system of shared meaning in the form of values, beliefs and habits interacts with the formal structure of the organization, resulting in norms of behavior.

There is an attachment to the entrenched value of the organization from the management and members of the POPTI city of Surabaya, at an ideal level it can be interpreted that the success of an organization is greatly influenced by the performance of its members. The performance by the POPTI management of Surabaya city is understood as a work achievement, because it brings together various backgrounds of its members as a large family of thalassemia sufferers. This form of performance is a collaboration between each other in terms of care during the Dr. Soetomo Surabaya hospital, indirectly the contribution of fellow members gives value to empowerment learning.

Parents who are administrators or members of the POPTI city of Surabaya have shown a commitment in helping parents whose children suffer from thalassemia, from here can be described as the loyalty of the members of the organization. This loyalty can be understood as a commitment based on a sense of family as a fellow parent whose child has thalassemia in the city of Surabaya. When this organizational commitment has been established, it is easy to achieve organizational goals, ideally this commitment includes acceptance and trust in the values and goals of the organization, feelings of involvement, and a sense of loyalty to the organization. In other words, organizational commitment is a sense of attachment and full support for the organization and its goals.

Assistance carried out for some time by administrators to adult thalassic patients, helped provide them insight into knowledge, and abilities to other patients. However, even though the administrators continue to accompany each routine schedule, because new adult members have not been fully capable in some ways, for example, approaches to doctors, nurses, or drug dealers. But their knowledge in terms of helping the administrators was enough to help other patients while exercising control at Dr. Soetomo hospital.

\section{Conclusion}

Even though there are still many shortcomings but the handling of thalassemia patients in Indonesia can be said to be more focused after the POPTI organization, especially for the areas that have the potential to develop this disease, especially for the Surabaya region, the parents of POPTI organizations in Surabaya provide many benefits in the care of their children. suffering from thalassemia, especially during treatment or routine control at Dr. Soetomo Surabaya Hospital. The assistance from the management of the POPTI organization in the city of Surabaya turned out to provide the value of empowerment for the parents of patients because it was formed from the value of togetherness as a fellow parent whose child suffered from thalassemia. The value of the sense of togetherness is a commitment for adult patients to provide tiered learning to patients whose status is from pediatric patients to patients of adult patient status, this makes the POPTI organizers of Surabaya city assisted in terms of mentoring other patients.

\section{References}

Bogdan, R.C \& Biklen, S.K.B. 1998. Cualitative Research for Education to Theory and Methods. Allyin and Bacon, inc. Boston. 
Chakraborty, A.K. 2002. Development Of Predictive Model For Optimum Blast Design In Mine Roadways In Tunnels Under Various Rock Mass Conditions. PhD Thesis, Indian School of Mines, Dhanbad, India.

Ife, J. dan Tesoriero, F. 2006. Community Development: Community-Based Alternatives in an Age of Globalisation. Edisi Ketiga. Pearson Education Australia. Terjemahan Sastrawan

M, Y. Nurul,dan Nursyahid. 2008. Community Development: Alternatif Pengembangan Masyarakat di Era Globalisasi. Cetakan I, Yogyakarta: Pustaka Pelajar.

Mardikanto, Totok. 2010. Konsep-konsep Pemberdayaan Masyarakat. Fakultas Pertanian UNS- UPT Penerbitan dan Pencetakan UNS (UNS Press). Surakarta.

Robbins, Stephen P. 2001. Perilaku Organisasi: Konsep, Kontroversi, Aplikasi, Jilid. 1, Edisi 8 , Prenhallindo, Jakarta.

Suhandojo. 2002. "Pengembangan Wilayah Pedesaan dan Kawasan Tertentu: Sebuah Kajian Eksploratif”. Jakarta: Badan Pengkajian dan Penerapan Teknologi (BPPT).

Suharto, Edi. 2014. Membangun Masyarakat-Memberdayakan Rakyat (Kajian Strategis Pembangunan Kesejahteraan Sosial dan pekerjaan Sosial). PT.Refika Aditama. Bandung.

Strauss, Aand Corbin, J. 1990. Qualitative Research; Grounded Theory Procedure and. Techniques. London: Sage Publication

UNDP. 1990. Human Development Report 1990. New York : Oxford University Press

Wahidayat, I. 2009. Thalasemia dan Permasalahannya di Indonesia. Naskah Lengkap KONIKA XI. IDAI. Jakarta.

Source of Regulation of the Republic of Indonesia: Peraturan Menteri Kesehatan No1109/Menkes/Per/VI/2011 Tentang Petunjuk Teknis. Jaminan Pelayanan Pengobatan Thalassaemia. Dengan Rahmat Tuhan Yang Maha Esa. Menteri Kesehatan Republik Indonesia.

Internet Source: Roemintoyo. 2013. Manajemen Kultur Sekolah (Konsep, Operasional, dan Temuan-Temuan Penelitian). https://jurnal.uns.ac.id/jptk/article/view/12624/10744. Vol. VI No.2. Di akses 25 Maret 2018, Pukul 02.20.WIB.

https://jpp.go.id/humaniora/kesehatan/305925-pengidap-thalasemia-di-indonesia-capai-8011-kasus diakses 29 Maret 2018, Pukul 04.29 WIB. 